\title{
HIV/AIDS - the problem in Polish prisons
}

\author{
Maria Łukaszek \\ Chair of Social Rehabilitation Pedagogy, Faculty of Pedagogy, University of Rzeszów, Rzeszów, Poland
}

\begin{abstract}
Introduction: The author has decided to study the issues herein because there is very little research on human immunodeficiency virus (HIV) infections of prisoners in Polish correctional facilities, and efficient penitentiary action should be based on good analysis of the problem.

Material and methods: The author presents herein the results of analyses of HIV infections among Polish prisoners in the years 2005-2016 and the results (diagnostics surveys) received from her research projects on the sample of 485 prisoners (2013-2014) and 210 prison service officers (2015-2016).

Results: The official number of newly detected HIV infections (2008-2016) is 72 per 100,000 persons and the number of HIV infected prisoners is 280 per 100,000. The officers estimated that the real number of HIV-infected prisoners is 5870 per 100,000 (only direct charges of the officers). The prisoners admitted to frequent sexual activity without using contraception and risky sexual behaviours, which is probably the main reason for their infections. Notwithstanding, the majority of prison officers are against giving or selling condoms to prisoners and their sex education.

Conclusions: The study results suggest that the problem of HIV infections among prisoners is much bigger than the official data show. As a result, it is astonishing that Prison Service officers are so unwilling to provide prisoners with condoms and sex education.
\end{abstract}

HIV AIDS Rev 2019; 18, 3: 199-206 DOI: https://doi.org/10.5114/hivar.2019.88195

Key words: AIDS, sexual health, HIV prevention, HIV infections.

\section{Introduction}

The sexual health of prisoners serving sentences in Polish correctional facilities is rarely studied or described in research/theoretical analyses. Moreover, the problem persists in spite of the Prison Service's alarming statistical data, which reveal that the number of prisoners infected with human immunodeficiency virus (HIV) and other sexually transmitted diseases is very high and the rehabilitation difficulties resulting from chronic depravation of prisoners' sexual needs.

The aim of the material presented above is:

- to define the epidemiological situation concerning HIV infections in Polish correctional facilities,

- to show the magnitude of risky sexual behaviours in prisoners' lives, which could have and still can provoke virus infections,

- to show opinions of Prison Service officers on the problem of HIV infections among prisoners (the magnitude of the problem and the role of the Prison Service in HIV prevention).

The concept of the presented material is based on the following assumptions:

- despite the fact that prisoners have been convicted to serve prison sentences, they still have the right to maintain their health, including sexual health [cf. 1-4]);

- the sexual health of prisoners can be endangered by their risky lifestyles both at large and in prison [cf. 5-8];

Article history:

Received: 08.04.2018

Received in revised form: 01.10.2018

Accepted: 13.02.2019

Available online: 05.06.2019
International Journal of HIV-Related Problems

HIV \& AIDS

R e v i e w 
- only qualified prison officers of a health-conscious attitude can efficiently implement programmes promoting prisoners' sexual health [cf. 9];

- taking care of the sexual health of prisoners is in the interest of the society to which they will finally return $[10,11]$. According to Polish law, every prisoner has the right to maintain their health, including sexual health. One of the factors contributing to good sexual health is providing prisoners with health services and hygiene conditions that are relevant to their needs (art. 102 of k.k.w.) [3]. Maintaining good sexual health by prisoners is extremely important. According to the World Health Organisation, sexual health is a unity of biological, intellectual, and social aspects of sexual life, which are indispensable for a full development of one's personality, communication skills, and love [2, 12]. Sexual health helps every individual to fulfil their life aspirations and to change the society in a creative way, which is one of the penitentiary's rehabilitative aims. Striving for ideal sexual health is an important element that improves the quality of everyone's life and affects the development of every human being [cf. 13].

Sexual health, which encompasses physical, emotional, and social well-being, means also the lack of sexual diseases and ailments $[2,12]$. Being in a good health is conditioned by motivation and knowing how to gain both satisfying and safe sexual experiences [14].

In the report of the National AIDS Centre from 2008, it was stated that HIV infections in Poland result mainly from risky sexual behaviours (87\%), having sex without condoms (38\%), having sex under the influence of alcohol, THC, or amphetamine, and drug injections (26\%). Thirty-nine per cent of seropositive men have had sexual intercourse under the influence of alcohol, heroin, or amphetamine, $24 \%$ of them have had more than five sexual partners per year, $41 \%$ more than five partners, and 54\% declared having had sex not only with their regular sex partners [15]. According to other research of the National AIDS Centre (2014), HIV-infected men believe that the direct reason for their infections were risky sexual behaviours undertaken under the influence of alcohol (30\%) and drugs (11\%), accidental sexual contact with numerous partners $(16 \%)$ - in the previous year they had five or more random partners; having sex without a condom: with a regular partner $-2 \%$, with a new partner $-5 \%$. Eight per cent of the HIV-infected men admitted having used intravenous drugs, $20 \%$ of them admitted having used other drugs; $22 \%$ of the interviewees used the same needles with other persons (however, not necessarily for drug injections $-23 \%$ of the respondents had a tattoo and $10 \%$ of them had piercings in non-sterile conditions) [16].

Speaking of prisoners, it is known that:

- risky sexual behaviours constitute a dominant element of prisoners' sexual mores, in particular, the ones belonging to a subculture $[17,18]$,

- a great proportion of prisoners have a problem with psychoactive drugs - according to the statistical data of the Police from the years 2000-2012, on average 31\% of all suspects were under the influence of alcohol (although the majority of them refused alcohol tests). In the group of suspects who agreed to alcohol tests, $65 \%$ of them were intoxicated [19],

- a lot of the prisoners have regularly taken drugs (19.5\% before being sentenced, $22.5 \%$ while being imprisoned) [20]; in the past 12 months before being sentenced to prison, $20.3 \%$ of the respondents used Cannabis indica, $14.9 \%$ - amphetamine, $10.7 \%$ - sedatives and soporific drugs, and 9.5\% - ecstasy pills; and while being in prison $18.9 \%$ of them used tranquilisers, $18.3 \%$ - cannabis, $14.8 \%$ - amphetamine, $12.8 \%$ - vodka, and $12.4 \%$ - moonshine [21],

- $40.4 \%$ of the prisoners got a tattoo in a correctional facility [5].

To sum up, it is not surprising that the percentage of prisoners infected with HIV is so high.

The statistical data of the Prison Service (the average number from the years 2005-2016) show that 280 per 100,000 prisoners in Polish correctional facilities are HIV infected [22]. A report of the National AIDS Centre additionally revealed that the real number may be even greater. Among all the prisoners interviewed in 2007, 0.6\% admitted being infected with HIV and $6.4 \%$ suppose that they may be infected [5].

The Polish Prison Service is aware of the seriousness of the problem and of the infections among the population of prisoners, and that is why they take part in the implementation of many prevention programmes, such as the National Programme on Counteracting Drug Addiction, the health programme of the Polish Ministry of Health entitled "RV treatment of HIV-infected persons in Poland", and the National Programme for Preventing HIV Infections and Combating AIDS. The most important benefits of the programmes are: methadone programme implementation for prisoners [23], ARV treatment of prisoners - the average number of prisoners who underwent the treatment in the years 2007-2016 was 218 [22], new therapy wards for addicts, organising conferences and trainings such as Join Action carried out as part of the third Programme for the $\mathrm{Eu}$ ropean Union's action in the field of health (2014-2020), or HA-REACT "HIV and Co-infection Prevention and Harm Reduction". Nevertheless, the number of HIV-infected prisoners is so high that it seems that all the actions are not sufficient to solve the problem.

\section{Material and methods}

The presented material shows the analyses done by the author on the basis of the data on prisoners' health provided by the Prison Service. The information was retrieved from annual data from the years 2005-2016 (http://www. sw.gov.pl/strona/statystyka-roczna accessed on $3^{\text {rd }}$ November 2017). Additionally, the author has presented herein the results of two other research projects: "Men serving prison sentences with regard to sex life and female sex partners" (a project carried out in the years 2013-2014, research grant 
funded by the funds of the Faculty of Pedagogy, University of Rzeszów, as a part of PE/WP/IX/Pb) and "Prison Service with regard to prisoners' sexual health" (research grant funded by the funds of the Faculty of Pedagogy, University of Rzeszów, as a part of $\mathrm{PE} / \mathrm{WP} / \mathrm{IV} / \mathrm{Pb}$ ) (Table 1), carried out by the author in nine correctional facilities subject to the Regional Prison Service Inspectorate in Rzeszów. In total, 485 men serving prison sentences and 210 Prison Service officers were interviewed.

The choice of the research sample, including both prisoners and Prison Service officers, was random, but the author took into account the quota (including the correctional facility type). First of all, the facilities were divided into three types: closed, open, and semi-open. The author randomly chose from them the following samples: juveniles, prisoners serving sentences for the first time, and repeat offenders. The number of individuals was proportional to their actual number in a particular correctional facility. Finally, when the individuals were chosen, the author randomly selected the respondents.

The research method was a study survey - more precisely, a questionnaire. The questionnaires were prepared by the author of the present research. The variables were subject to operationalisation, and the tools were verified using the competent expert method (researchers and Prison Service officers). Both projects were preceded by pilot research.

The research was prepared and carried out according to "Good Manners in Science" drawn up by the Polish Academy of Sciences [24] and other principles regarding the ethics of social research (the projects were financed from the funds of the Faculty of Pedagogy of the University of Rzeszów af ter having received substantive and ethical acceptance). To provide the respondents with answer anonymity and a sense of security, the author carried out all the surveys in person. The selected persons were informed about the course of the study, anonymity rules, and the fact that the research was carried out on a voluntary basis. For the author and the research itself, the most important thing was to receive prisoners' conscious and voluntary permission to take part in the research. This was extremely important, taking into account the current social status and life situation of the prisoners, who might have felt under pressure from Prison Service officers.

The study was done in small groups (min. surface of $4 \mathrm{~m}^{2}$ per person). Moreover, according to the procedures, the Prison Service officers did not approach the men while filling in the questionnaires, but they could only watch them from distance. After having filled in the questionnaires, the research author picked them up folded in white envelopes. After having participated in the study, the prisoners were guaranteed specialist help (from a sex educator and psychologist).

The questionnaires among Prison Service officers were carried out in groups of 10-20 persons in conference rooms at the premises of the correctional facilities.

\section{Results}

\section{The epidemiological situation of the population of prisoners in Poland}

As Table 2 reveals, both newly detected HIV infections and the number of the HIV infected are very high; however, the data show only a general tendency. In Poland, annually, only 4081 tests are done (the average for the years 20082016), which amounts to only $5.02 \%$ of all examined prisoners [22].

The analysis revealed that the newly detected HIV infection ratio is 72 per 100,000 prisoners (the average for the years 2005-2016) and it has been decreasing for the last eight years. The average number of HIV infected prisoners is 280 per 100,000 persons (the average for the years 2005-2016). Since 2005, the number has decreased almost four-fold.

Table 1. Respondents and phenomena studied as part of the projects carried out in the years 2013-2014 and 2015-2016

\begin{tabular}{|c|c|c|}
\hline $\begin{array}{c}\text { Research } \\
\text { year }\end{array}$ & Sample & Problems analysed \\
\hline 2013-2014 & $\begin{array}{l}N=485 \text { - men serving prison services } \\
\text { in correctional facilities in Jasło, Łupków, } \\
\text { Moszczaniec, Sanok, Przemyśl, Rzeszów, Dębica: } \\
\text { - Average age: } 35.8 \text { years old } \\
\text { - Total average sentence length: } 6.1 \text { years }\end{array}$ & $\begin{array}{l}\text { - Sexual activity while at large } \\
\text { - Sexual activity while in prison } \\
\text { - Attitudes towards sexual violence in the relations between } \\
\text { prisoners } \\
\text { - Relations with wives/sex partners } \\
\text { - Attitudes towards relations with wives/sex partners }\end{array}$ \\
\hline $2015-2016$ & $\begin{array}{l}N=210 \text { - Prison Service officers working in } \\
\text { correctional facilities in Jasło, Łupków, Uherce } \\
\text { Mineralne, Sanok, Medyka, Przemyśl, Rzeszów, } \\
\text { Dębica } \\
\text { - } 35 \text { women and } 175 \text { men } \\
\text { - } 88 \text { - tutors, psychologists, therapists, } 114 \\
\text { prison officers, and } 8 \text { administrative workers }\end{array}$ & $\begin{array}{l}\text { - Assessing the frequency of having sex by prisoners serving } \\
\text { sentences in correctional facilities } \\
\text { - Assessing the prevalence of sexually transmitted diseases } \\
\text { among prisoners } \\
\text { - Opinions on prisoners' sexual health } \\
\text { - Opinions on the responsibilities of the Prison Service on } \\
\text { the prevention of prisoners' sexual health }\end{array}$ \\
\hline
\end{tabular}

Source: Author's individual research - project carried out in the years 2013-2014 and 2015-2016 
Table 2. HIV infections among women and men in Polish correctional facilities in the years 2005-2016

\begin{tabular}{l|c|c|c|c|c}
\hline Year & $\begin{array}{c}\text { Number } \\
\text { of prisoners }\end{array}$ & $\begin{array}{c}\text { Number of newly } \\
\text { detected infections }\end{array}$ & Population (\%) & $\begin{array}{c}\text { Numbers of HIV-infected } \\
\text { prisoners as of 31 } 1^{\text {st }} \text { December }\end{array}$ & Population (\%) \\
\hline 2016 & 71,456 & 38 & 0.053 & 100 & 0.140 \\
\hline 2015 & 74,814 & 31 & 0.041 & 128 & 0.171 \\
\hline 2014 & 78,987 & 52 & 0.066 & 167 & 0.211 \\
\hline 2013 & 83,898 & 46 & 0.055 & 182 & 0.217 \\
\hline 2012 & 84,399 & 34 & 0.040 & 112 & 0.133 \\
\hline 2011 & 82,558 & 48 & 0,058 & 171 & 0.207 \\
\hline 2010 & 82,863 & 52 & 0.063 & 179 & 0.216 \\
\hline 2009 & 85,384 & 72 & 0.084 & 251 & 0.294 \\
\hline 2008 & 85,920 & 88 & 0.102 & 281 & 0.327 \\
\hline 2007 & 89,955 & 81 & 0.090 & 378 & 0.420 \\
\hline 2006 & 87,370 & 89 & 0.102 & 433 & 0.496 \\
\hline Average & 82,530 & 87 & 0.105 & 434 & 0.524 \\
\hline
\end{tabular}

Source: Data provided by the Prison Service [22]

Table 3. Newly detected HIV infections in Poland among women and men in the whole of Poland and Polish correctional facilities in the years 2005-2015

\begin{tabular}{l|c|c}
\hline Years & $\begin{array}{c}\text { Poland/rate } \\
\text { per 100,000 persons }\end{array}$ & $\begin{array}{c}\text { Prisoners/rate } \\
\text { per 100,000 persons }\end{array}$ \\
\hline 2015 & 3.2 & 41 \\
\hline $2010-2014$ & 2.8 & 56 \\
\hline $2005-2009$ & 2.1 & 97 \\
\hline
\end{tabular}

Source: Data provided by the Prison Service [22] and the National Institute of Public Health and National Institute of Hygiene [25, 26]

Table 4. Comparison of sexual experiences of non-prisoners from the whole of Poland and prisoners (in \%)

\begin{tabular}{|c|c|c|}
\hline $\begin{array}{l}\text { Forms of sexual } \\
\text { activities }\end{array}$ & $\begin{array}{l}\text { Izdebski, } 2005 \\
\quad N=1615, \\
\text { a representative } \\
\text { sample of men } \\
\text { from the whole } \\
\text { of Poland }\end{array}$ & $\begin{array}{c}\text { Łukaszek, } \\
2013-2014 \\
N=485, \\
\text { prisoners }\end{array}$ \\
\hline Oral sex & 49.6 & 82.9 \\
\hline Ejaculation in mouth & 29.7 & 60.4 \\
\hline Anal sex & 19.7 & 47.6 \\
\hline Group sex & 7.5 & 14.8 \\
\hline Taking money for sex & 3.5 & 8.7 \\
\hline Paying for sex & 11.4 & 42.1 \\
\hline
\end{tabular}

Source: Author's individual research - project carried out in the years 20132014 and Izdebski [28: 558-559].

As the table shows, the number of newly detected HIV infections in correctional facilities is many times higher than among non-prisoners from all over Poland. Nevertheless, it is stated that the ratio among prisoners is decreasing, whereas it is increasing among non-prisoners all over Poland. The percentage of HIV prisoners in the years 2005-2009 was 46 times higher and in 2015 it was 12 times higher than all over Poland.

Speaking of the number of the HIV infected (in 2016), in Poland it was 51 per 100,000 persons [25] and among prisoners, it was 140 per 100,000 persons [22].

\section{Risky sexual behaviours as possible factors provoking HIV infections among men serving prison sentences}

Taking into account the possibility of being HIV infected, the riskiest forms of sexual activity without using a condom are: fellatio (active one), ejaculation in mouth, vaginal sex, anal sex (passive and active), and using the same sex toys [27].

The research results (Table 4) show that the respondents have experienced various risky forms of sexual activity in a two-fold higher percentage than men from all over Poland. Moreover, the number of prisoners who admitted to having paid for sex is four times higher than among the non-prisoners. Finally, in the prevention of HIV infections, using condoms is more important than limiting the number of sex partners.

According to the gathered data, the most frequent forms of sexual activity without a condom undertaken by the prisoners who took part in the research were: sexual intercourse with unknown (54.4\%) or little known (51.3\%) persons; having sex when both partners were under the influence of alcohol (49.7\%) or when only the person asked (43.5\%) or his partner (22.9\%) was under the influence of alcohol, having sex when the respondent was drug intoxicated (23.1\%) or when both partners were under the influence of drugs (21\%); and using sex services (21.1\%). 
Table 5. Risky sexual activities without a condom, sample of 485 men (in \%)

\begin{tabular}{|c|c|c|c|c|c|}
\hline \multirow[t]{2}{*}{ Risky sexual behaviours without using a condom } & \multicolumn{5}{|c|}{$\begin{array}{l}\text { Frequency (in \%) } \\
\qquad N=485\end{array}$} \\
\hline & Never & Once & $\begin{array}{l}\text { A couple } \\
\text { of times }\end{array}$ & $\begin{array}{l}\text { More than } \\
\text { ten times }\end{array}$ & No answer \\
\hline Having sex with a completely unknown person & 43.5 & 7.8 & 33.8 & 12.8 & 2.1 \\
\hline Having sex with a little-known person & 46.6 & 7.2 & 31.5 & 12.6 & 2.1 \\
\hline Using sex services & 77.9 & 2.9 & 11.8 & 5.4 & 2.1 \\
\hline Providing sex services & 91.3 & 0.2 & 3.3 & 3.1 & 2.1 \\
\hline Group sex & 88.2 & 2.9 & 4.1 & 2.7 & 2.1 \\
\hline Forcing somebody to vaginal sex & 92.6 & 0.6 & 3.9 & 0.8 & 2.1 \\
\hline Forcing somebody to oral sex & 92.8 & 1.9 & 3.1 & 0.2 & 2.1 \\
\hline Forcing somebody to anal sex & 93.2 & 0.6 & 3.3 & 0.8 & 2.1 \\
\hline Having sex under the influence of alcohol & 54.4 & 4.3 & 25.8 & 13.4 & 2.1 \\
\hline Having sex with a person under the influence of alcohol & 75.1 & 2.5 & 16.1 & 4.3 & 2.1 \\
\hline $\begin{array}{l}\text { Having sex while both partners were under the influence } \\
\text { of alcohol }\end{array}$ & 48.2 & 2.3 & 31.1 & 16.3 & 2.1 \\
\hline Having sex while being intoxicated & 74.8 & 0.8 & 13.6 & 8.7 & 2.1 \\
\hline Having sex with a drug-intoxicated person & 87.6 & 0.8 & 6.8 & 2.7 & 2.1 \\
\hline Having sex while both partners were drug intoxicated & 76.9 & 1.6 & 10.7 & 8.7 & 2.1 \\
\hline
\end{tabular}

Source: Author's research data gathered in the years 2013-2014

Table 6. Sex education issues for prisoners approved by prison officers (in \%)

\begin{tabular}{l|c}
\hline Issues to be discussed as a part of sex education for prisoners & $\begin{array}{c}\text { Number of officers in favour (in \%) } \\
\text { N }=210\end{array}$ \\
\hline Lack of consent to prisoners' sex education & 26.2 \\
\hline III. Prevention of sexually transmitted diseases and sexual disorders (except for paraphilia) & 68.6 \\
\hline VII. Risky sexual behaviours (e.g. promiscuous lifestyle, prostitution, sexual violence) & 55.7 \\
\hline IV. Body hygiene, sexual functions control & 49.1 \\
\hline I. Morality in relationships (respect, positive engagement of both partners) & 47.6 \\
\hline VIII. Men's determinants of sexual disorders & 46.7 \\
\hline VI. Sexual problems in correctional facilities & 42.9 \\
\hline IX. Men's problems regarding their sexual lives (sex orientation, anxieties, paraphilias) & 38.6 \\
\hline II. Biological aspects of sexual life (development, fertility) & 32.4 \\
\hline V. Ideology regarding sexual life & 23.3 \\
\hline
\end{tabular}

Source: Author's research data gathered in the years 2015-2016.

Speaking only of the men who have undertaken the abovementioned forms of sexual activity, it turned out that 47.7$90.9 \%$ of them did not use condoms. They did not use contraception mainly when both partners were drug intoxicated (90.9\%); when only the respondent $(88.2 \%)$ or their partner (85.1\%) was drug intoxicated; when both partners were under the influence of alcohol (87\%); and when they forced a partner to have oral sex (85.2\%) and anal sex (83.9\%).

When it comes to the risk of being HIV infected, it is worth mentioning that the respondents have experienced sexual contact with many partners $-24 \%$ of them declared to have had sex with more than five partners before turning 18 . The average number of partners in the prisoners' lives so far (the average age 36 years) was 15 . Moreover, $3.3 \%$ of the respondents provide sex services on the premises of the correctional facilities they are actually in, which is also very risky taking into account the possibility of being HIV infected.

Prisoners who undertake risky sexual behaviours are much more likely to get infected with HIV. As the research of Swartz, Lurigio, and Weiner [29] reveals, paradoxically, persons who decide to undertake risky sexual behaviours find them much less dangerous than the ones who avoid 
them. Hence, it may be assumed that the ones who go for risky behaviours have much lower motivation to undergo HIV tests.

\section{Prison officers' opinions on the problem of HIV among prisoners}

The project aim (2015-2016) was to answer the following questions:

- What is the scale of HIV infections among prisoners according to the Prison Service? (Prison officers made their estimations on the basis of their experience with the penalty groups they knew well and worked with on a daily basis.)

- What are prison officers opinions on their role in the prevention of HIV infections among prisoners?

It was stated that the estimated number of HIV-infected prisoners is 5870 per 100,000 men. A higher number was mentioned by the following prison employees:

- officers working in the Security Department $(p=0.038$; Cramer's V $=0.197$; Pearson's C $=0.314$ ),

- officers working in closed correctional facilities ( $p=0.014$; Cramer's V $=0.243$; Pearson's $C=0.295)$,

- officers with less experience (6-10 years) ( $p=0.041$; Cramer's V = 0.186; Pearson's C $=0.348)$.

Although the official number of HIV infected prisoners serving their sentences in Polish correctional facilities is 280 out of 100,000 (in the years 2005-2016), the real number is estimated to be 21 times higher. The estimation may be done taking into account the knowledge of prison officers, which is more reliable, and the officers themselves can certainly be treated as competent experts in the research. As was mentioned at the beginning of the article, according to a survey from $2007,7 \%$ of the prisoners know that they are HIV infected or they suppose that it is highly probable [5: 53]. According to their declarations, it may be assumed that the real number of the HIV-infected prisoners is 6007000 out of 100,000 . As the WHO reveals, the number of the HIV infected in correctional facilities in Western Europe is $1 \%$ higher. In the neighbouring countries of Poland, the numbers of the HIV-infected in correctional facilities, dependent on the prison type, are as follows: Ukraine 0-26\%, Slovakia - 0-34\% [1], Estonia 15.6\% [30].

While carrying out the research, the author was trying to ascertain prison officers' opinions on providing prisoners with condoms. As it turned out, prison officers are fierce opponents of giving prisoners access to condoms. $87.1 \%$ of them think that it is inappropriate to give condoms to prisoners, and $66 \%$ do not agree even to their purchase. $10 \%$ of the prison officers opted for giving the prisoners a possibility to buy condoms and $6.7 \%$ opted for giving them away for free. The fiercest opponents of free access to condoms are officers working in the Security Department (82.5\%) and administration employees (75\%) ( $p=0.000001$; Cramer's $\mathrm{V}=0.3$; Pearson's $\mathrm{C}=0.464)$. Although prison officers' opinions on free access to condoms were similar, there was no correspondence determined between their professional position and opinion. Moreover, the research revealed that not only do prison officers not find it necessary to give away or sell condoms, but they also see no point in prisoners' sex education. $55.7 \%$ of the respondents opted for such education, but only $16.7 \%$ professionals were strongly convinced about its need. The opponents of sex education are mainly:

- officers working in the Security Department and administration employees ( $p=0.036$; Cramer's V $=0.193$; Pearson's $\mathrm{C}=0.314$ ),

- persons who are not very satisfied with their professional jobs ( $p=0.048$; Cramer's V $=0.177$; Pearson's $C=0.374$ ).

It is astonishing that $26.2 \%$ of the professionals deny the need for sex education among prisoners. From the list of 27 indications regarding nine domains of sex education, the prison officers most often (68.6\%) accepted the issues concerning sexually transmitted diseases and sexual disorders (except for paraphilia). The respondents could mark three activities aimed at disease and disorder prevention, and only $31.4 \%$ of them marked all of them as important. The fiercest opponents of sex education are officers working in the Security Department (42.1\%), who constituted only a half of the prison officers $(72.2 \%)$, who marked two or three questions enumerated in the table above $(p=0.0002$; Cramer's V $=0.270$; Pearson's $C=0.417$ ).

The most supported the opinion (65.2\%) within the third question group from the table (the problem of sexually transmitted diseases and sexual disorders), which was that prisoners should be provided with knowledge on how to prevent HIV infections. However, the lowest number supported the opinion stipulating that prisoners should be provided with the knowledge on how to diagnose sexually transmitted diseases including HIV infections, prostatic hypertrophy, and sexual disorders (34.4\%). Possibly, prison officers are afraid that the knowledge on how to diagnose diseases will result in more frequent examinations of prisoners, and higher numbers of infections and diseases officially revealed, which may lead to the implementation of long and onerous treatment procedures.

\section{Discussion}

The presented material shows that the official number of newly detected HIV infections (for the years 2008-2016) in the population of prisoners is 72 infections per 100,000 persons, and it is 24 times higher than in all of Poland. The number of prisoners infected with HIV (in the years 2005-2016) was 280 per 100,000 prisoners. However, it is estimated that both ratios are still decreasing, which is very positive, taking into account that in the population of non-prisoners the tendency is contrary. Moreover, the majority of the HIV infected in Polish correctional facilities undergo antiretroviral treatment.

Despite the positive information, according to prison officers, the percentage of HIV infected prisoners may be much higher. In their opinion, it can be as much as 5870 per 100,000 prisoners (which is 21-times more than the official data from the years 2005-2016 show). Moreover, it is very probable that the estimations regarding the prisoners whom 
prison officers know well and take care of within their penal groups are more accurate than the official statistics indicate and, in particular, that the estimations of penitentiary workers are much closer to the data provided by European correctional facilities $[1,30]$.

As the declarations of the men serving prison sentences who took part in the research show, their sexual contact is very risky, which may be the reason for the high percentage of HIV infections. There are five highly risky activities, and they are the following: taking up sexual contact with numerous unknown or little-known persons, commercial sexual contacts, violent sexual activity, taking up sexual activities under the influence of alcohol and drugs, and (regular) sexual contact without using condoms. The conclusion is identical to that drawn by Butler et al. [31], who found out that the percentage of prisoners who have experienced a variety of risky sexual contact is much higher than among non-prisoners.

As Gear and Ngubeni [7], and Krebs [8] underline, the virus can be further transmitted in correctional facilities as a result of risky sexual contacts between prisoners. As Richters et al. reveal, $7.1 \%$ of prisoners have had voluntary sexual contact and other $2.6 \%$ have experienced sexual contact against their will [6]. Butler's research team found out that $9 \%$ of the men had had voluntary sexual contact with their fellow prisoners [31].

Speaking of risky sexual activities undertaken by prisoners, it is highly probable that their sexual conduct is the reason for the majority of HIV infections [cf. 6-8, 31].

The HIV/AIDS prevention activities undertaken by the Prison Service in Poland described in the introduction might be seen as complex and efficient. But unfortunately, as Hariga underlines, efficient implementation of programmes promoting sexual health among prisoners is conditioned mainly by the competences and pro-health attitudes of the employees who directly work with prisoners [cf. 32].

Nevertheless, the individual research of the author reveals that a great proportion of prison officers (particularly the ones from the Security Department) who work with prisoners on a daily basis do not accept their right to sexual health. Not only do the majority of the officers not find it necessary to give away or to sell condoms, but they also think that sex education among prisoners is pointless (it also concerns the knowledge on how to diagnose some diseases). It is astonishing that professionals do not feel responsible for the social life to which, as Testa et al. underline, the majority of prisoners will come back sooner or later [10]. They are probably not conscious that prisoners' good sexual health should be important for the society to which the prisoners will return $[11,30]$. It is important that common sex education and an access to condoms could motivate prisoners to undergo medical examinations and, if necessary, treatment, but also to impede the virus transmission while serving prison sentences and later on.

\section{Conclusions}

It was stated that the official number of newly detected HIV infections (2008-2016) is 72 per 100,000 persons and the num- ber of HIV infected prisoners is 280 per 100,000 . The officers estimated that the real number of HIV-infected prisoners is 5870 per 100,000 (only direct charges of the officers).

The prisoners admitted to frequent sexual activity without using contraception and risky sexual behaviours, which is probably the main reason for their infections. Notwithstanding, the majority of prison officers are against giving or selling condoms to prisoners, or their sex education.

\section{Conflict of interest}

The authors declare no potential conflicts of interest with respect to the research, authorship, and/or publication of this article.

\section{References}

1. World Health Organization, Regional Office For Europe. Available at: http://www.euro.who.int/en/health-topics/communicablediseases/hivaids/policy/policy-guidance-for-key-populations-most-at -risk2/hiv-inprisons (Accessed: 20.12.2017).

2. World Health Organization. Regional Office for Europe, 2001. WHO Regional Strategy on Sexual and Reproductive Health. Copenhagen. Available at: www.euro.who.int/document/e74558. pdf (Accessed: 12.02.2018).

3. Law from the $6^{\text {th }}$ June 1997, Kodeks Karny Wykonawczy [The executive penal code] (Dz. U. [Journal of Laws] 1997, no. 90, item 557 with further modifications), art. 102.

4. Helsińska Fundacja Praw Człowieka [Helsinki Foundation for Human Rights]. (2017). Raport prawa osób pozbawionych wolności Polska. Warszawa, May 2017. Available at: http://www.hfhr.pl/wp-content/ uploads/2017/05/Report-CPT-PL.pdf (Accessed: 21.11.2017).

5. Krajowe Centrum ds. AIDS [National AIDS Centre] (2007). Zdrowie $\mathrm{w}$ więzieniu - badanie postaw, zachowań i wiedzy personelu więziennego oraz ludzi pozbawionych wolności na temat chorób zakaźnych w wytypowanych polskich jednostkach penitencjarnych. Europejska Sieć Współpracy na Rzecz Przeciwdziałania Narkomanii i Infekcjom w Więzieniach (ENDIPP). Available at: https://aids.gov.pl/badania_ spoleczne/248/ (Accessed: 10.10.2017).

6. Richters J, Butler T, Schneider K, et al. Consensual sex between men and sexual violence in Australian prisons. Arch Sex Behav 2012; 41: 517-524.

7. Gear S, Ngubeni K. Daai ding: sex, sexual violence and coercion in men's prisons. Available at: http://www.csvr.org.za/docs/correctional/daaidingsex.pdf (Accessed: 22.01.2018).

8. Krebs CP. High-Risk HIV transmission behavior in prison and the prison subculture. Prison Journal 2002; 82: 19-49.

9. World Health Organization. Poradnik Światowej Organizacji Zdrowia (WHO) na temat infekcji HIV/AIDS w więzieniach. Genewa, 1993. Available at: http://www.harm-red.bci.pl/poradnik.htm (Accessed: 17.12.2017).

10. Testa AC, Weilandt C, Ncube F, Gill NO. HIV transmission in part of the US prison system: implications for Europe. Eurosurveillance 2006; 11. Available at: http://www.eurosurveillance.org/content/ 10.2807/esw.11.21.02962-en (Accessed: 18.11.2017).

11. Van der Meulen E, Watson TM, De Shalit A. Insights on prison needle and syringe programs: research with former prisoners in Canada. Prison Journal 2017; 97: 628-643.

12. World Health Organization. Defining Sexual Health. Report of a Technical Consultation on Sexual Health. WHO, 28-31, January 2002, Geneva. Available at: http://www.who.int/reproductivehealth/topics/gender_rights/defi ning_sexual_health.pdf (Accessed: 15.05.2016).

13. Woynarowska B. Edukacja zdrowotna. PWN, Warszawa 2008. 
14. Sadovsky R, Nusbaum M. Sexual health inquiry and support is a primary care priority. J Sex Med 2006; 3: 3-11.

15. Krajowe Centrum ds. AIDS [National AIDS Centre] (2008). Raport $\mathrm{z}$ analiz ankiet wypełnianych w Punktach Konsultacyjno-Diagnostycznych w roku 2008. Available at: https://aids.gov.pl/badania_ spoleczne/252/ (Accessed: 19.11.2017).

16. Krajowe Centrum ds. AIDS [National AIDS Centre] (2014). Raport $\mathrm{z}$ analiz ankiet z Punktów Konsultacyjno-Diagnostycznych z 2013 r. Available at: https://aids.gov.pl/badania_spoleczne/704/ (Accessed: 19.11.2017).

17. Szaszkiewicz M. Tajemnice grypserki. Wydawnictwo Instytutu Ekspertyz Sądowych, Kraków 1997.

18. Łukaszek M. Cechy obyczajowości seksualnej mężczyzn niedostosowanych społecznie. In: Mudrecka I (ed.). Resocjalizacja, readaptacja i reintegracja społeczna - problemy, programy i perspektywy rozwoju komunikacji. Pedagogium Wyższa Szkoła Nauk Społecznych, Warszawa 2017; pp. 219-230.

19. Policja [Police]. Available at: http://statystyka.policja.pl/st/wybrane-statystyki/nietrzezwi-sprawcy-prz/50862,Nietrzezwi-sprawcy -przestepstw.html (Accessed: 3.11.2017).

20. Sierosławski J. Narkomani w zakładach karnych i aresztach śledczych. Serwis Informacyjny Narkomania 2001; 2: 45-56.

21. Sierosławski J. Problem narkotyków i narkomanii w zakładach karnych i aresztach śledczych. Krajowe Biura ds. Przeciwdziałania Narkomanii, Warszawa 2007.

22. Centralny Zarząd Służby Więziennej [Central Board of Prison Service]. Roczna informacja statystyczna. Available at: http://www. sw.gov.pl/strona/statystyka-roczna (Accessed: 20.11.2017).

23. Centralny Zarząd Służby Więziennej [Central Board of Prison Service]. Available at: http://www.sw.gov.pl/strona/opis-areszt-sledczy-wkrakowie (Accessed: 5.12.2017).

24. Polska Akademia Nauk. Kodeks Etyki Pracownika Naukowego. Dom Wydawniczy ELIPSA, Warszawa 2017. Available at: https://instytucja.pan.pl/images/2016/komisja_etyki/Kodeks_etyki_pracownika_ naukowego_-_wydanie_II_-_2016_r.pdf (Accessed: 10.06.2018).

25. Narodowy Instytut Zdrowia Publicznego [National Institute of Public health], PZH (2016). Zakażenia HIV i zachorowania na AIDS w Polsce. Rosińska M, Niedźwiedzka-Stadnik M (eds.). Available at: http://wwwold.pzh.gov.pl/oldpage/epimeld/hiv_aids/index.htm (Accessed: 28.07.2017).

26. Wojtyniak B, Goryński P (eds.). Sytuacja zdrowotna ludności Polski i jej uwarunkowania. Narodowy Instytut Zdrowia Publicznego - Państwowy Zakład Higieny, Warszawa 2016. Available at: http:// www.sdgs.pl/wp-content/uploads/2017/06/sytuacja-zdrowotna -ludnosci-w-polsce-2016-s.pdf (Accessed: 28.07.2017).

27. Izdebski Z. Seksualność Polaków na początku XXI wieku. Studium badawcze. Wydawnictwo Uniwersytetu Jagiellońskiego, Kraków 2012.

28. Izdebski Z, Walendzik A. Psychospołeczne i medyczne aspekty epidemii HIV. In: Izdebski Z (ed.). Zachowania seksualne kobiet świadczących usługi seksualne, mężczyzn homoseksualnych i osób uzależnionych od narkotyków. Oragon, Zielona Góra 2000; pp. 9-20.

29. Swartz JA, Lurigio AJ, Weiner DA. Correlates of HIV-risk behaviors among prison inmates: implications for tailored AIDS prevention programming. Prison Journal 2004; 84: 486-504.

30. Kivimets K, Uusküla A. HIV testing and counselling in Estonian prisons, 2012 to 2013: aims, processes and impacts. Eurosurveillance $2014 ; 19$. Available at: http://www.eurosurveillance.org/about (Accessed: 21.11.2017).

31. Butler T, Richters J, Yap L, et al. Sexual health and behaviour of Queensland prisoners: with Queensland and New South Wales comparisons. National Drug Research Institute, Curtin University, and School of Public Health and Community Medicine, University of New South Wales, Perth and Sydney 2010.
32. Hariga F. HIV and other bloodborne viruses in prisons. In: Prisons and Health. Enggist S, Møller L, Galea G, Udesen C (eds.). Regional Office for Europe, WHO 2014. Available at: http://www.euro.who. int/_data/assets/pdf_file/0005/249188/Prisons-and-Health.pdf. pp. 45-55 (Accessed: 20.11.2017). 